\title{
Synthesis of Attaining Sustainable Development Goal 6.5: A Case Study of Mano River
}

\author{
Mohamed Yateh ${ }^{(0)}$, George Lartey-Young ${ }^{\circledR}$, Harrison Henry Boying, Fengting $\mathrm{Li}^{*}{ }^{(0)}$ \\ College of Environmental Science and Engineering, State Key Laboratory of Pollution Control and Resource Reuse Study, Tongji \\ University, Shanghai, China \\ Email: ^fengting@tongji.edu.cn
}

How to cite this paper: Yateh, M., Lartey-Young, G., Boying, H. H., \& Li, F. T. (2021). Synthesis of Attaining Sustainable Development Goal 6.5: A Case Study of Mano River. Journal of Geoscience and Environment Protection, 9, 100-119.

https://doi.org/10.4236/gep.2021.96006

Received: May 9, 2021

Accepted: June 18, 2021

Published: June 21, 2021

Copyright $\odot 2021$ by author(s) and Scientific Research Publishing Inc. This work is licensed under the Creative Commons Attribution International License (CC BY 4.0).

http://creativecommons.org/licenses/by/4.0/ (c) (i) Open Access

\begin{abstract}
The Mano River is a transboundary river that runs through Côte d'Ivoire, Liberia, Guinea, and Sierra Leone. According to a 2018 United Nation report on Sustainable Development Goal (SDG) 6.5, which aims to improve the adoption of cohesive water resource management by 2030; the impact of this goal on the Mano River management is minimal. The research summarizes previous studies using an integrative literature review method, drawing general conclusions and identifying unsolved problems with respect to water resources management. The research finding demonstrated that existing water stress and poor management as exacerbated by socioeconomic practices in the region are the major threats to achieve SDG 6.5. As a result of these activities, long-term management of the river basins has become extremely difficult. The research informs a discussion to achieve cooperative water resource management, which is best achieved by shared collaboration and shared interests as described by SDG 6.5 .
\end{abstract}

\section{Keywords}

Côte d'Ivoire, Guinea, Liberia, Mano River, Sierra Leone, Sustainable

Development Goal 6.5, Water Resource Management

\section{Introduction}

Sustainable Development Goal (SDG) 6.5 deals with implementing principally water resources management (WRM) and it has laid a solid foundation to attain indicator 6.5.1 and 6.5.2 which lay emphasis on Integrated Water Resource Management (IWRM) and Transboundary Water Resource Management (TWRM) 
respectively (Ladel et al., 2020). Water due to its high demand across nations has over time been categorized as an essential commodity for life and a potential precursor to a "third world" (Whittington et al., 2005). In general, transboundary rivers can be defined as an ecological structure that has an economic path (Boer et al., 2015). In about 54 percent of the world's transboundary river basins (Ashour et al., 2019), water resources security is considered as a current and potential danger due to human activities (Hojjat Mianabadi et al., 2013; Mumbi \& Li, 2020). Transboundary water resources comprise "water bodies" which traverse one or more national and political boundaries (Neir \& Campana, 2007; Teñido, 2017). Approximately 45\% of Earth's surface is occupied by a river basin of which an estimated 278 is shared by more than one nation (Armitage et al., 2015). In the context of international law of transboundary rivers, countries which share ownership of these "river" must exercise due right to control, regulate and manage them including all water resources (Boer et al., 2015). Water demand contributes to water use behavior changes and the production of stress conditions in transboundary water resources (Mumbi \& Li, 2020). Multifaceted matters of common concern usually arise from such shared natural area resources systems, ranging from management of environmental threats, regulating access, and accruing its benefit (e.g. mining) (Abebe, 2014).

To promote and ensure active collaboration for the management of the Mano River, Sierra Leone, Guinea, Liberia, and Cote d'Ivoire set up a governance system in each country's national portions and established an initiative named Mano River Union (MRU) (UN, 1974, Silberfein \& Conteh, 2006). The union was first formed between Sierra Leone and Liberia in 1973; Guinea joined the project in 1983 and was finally joined by Cote d'Ivoire in 2008 (UN, 1974). The MRU is considered one of the Western African regional integration institutions involving sharing countries and stakeholders. The union aims to manage the water resources and works towards a fair distribution of it to realize sustainable socio-economic development throughout the basin. In 1974, the MRU's treaty gave each country absolute rights over the river to expand their trade and other legal activities by creating favorable conditions to maintain mutual productive capacity and progressive development; the established treaty goals consider some of the following: 1) foster the international relationship between the members of the MRU, 2) source funds and overseeing projects for development (industry, transport, economic purposes, energy, resources, and food security) and 3) promote peace and stability in the region (UN, 1974).

Water availability in the Mano River Basin is decreasing due to a variety of reasons, including seasonal fluctuations in precipitation, and demand from an increasingly increasing population. Water use trends differ significantly across member states and regions in the Mano River Basin. Water from the Mano River is generally been used for residential, food preservation, biodiversity, and a variety of other activities; however, the Mano River's primary application is for agricultural purposes (Akitani, 2013). In 2013, the Board of the African Devel- 
opment Bank Group (AfDB) authorized the electricity networks interconnection project along the Mano River for Côte d'Ivoire, Liberia, Sierra Leone, and Guinea (CLSG) (Akitani, 2013). Hydropower, unlike irrigation, is considered a non-consumptive water consumption; despite not reducing flow rate, hydropower water usage changes the downstream flow management of a river (Mumbi $\& \mathrm{Li}, 2020)$. The MRU countries are either water-poor or water strained as a result of increasing water shortages and a reduction in per-capita water availability in the region, despite the region's population growth and socio-economic development (IUCN, 2012, Sankara-Bassonon et al., 2018).

Because of these fundamental reasons on the water use pattern, specific guidelines must be established to achieve the requisite balance between all member states' rights to create sustainable growth and management of the river basins. We evaluated the impacts of IWRM on the environment-related SDG 6.5 priorities in the Mano River basin that are likely to be impacted by WRM and for which there are available data and specific quantitative indicators. This study aimed to: 1) identify and evaluate the driving scenarios of the river basin's present situation, and 2) suggest management options for the basin water resources management to provide insights into IWRM. The results of this study will fill gaps in information about the Mano River basin management to help address some of the water security concerns and critical developments towards achieving SDG 6.5 within the next seven years or so.

\section{Materials and Methodology}

\subsection{Study Area}

The Mano River is rain-fed; its flows include Guinea's parrot break region, the Kailahun-Kono district of Sierra Leone, and the county of Lofa in Liberia; and it extends from Liberia to the Côte d'Ivoire via the Sanniquelle Channel, one of this river's unique characteristics (see Figure 1). The river is $320 \mathrm{~km}$ long, rising northeast of Voinjama in Liberia, and passes through the Guinea uplands and emptying into the Atlantic at Mano Salija, Sierra Leone (Britannica, 2015). A catchment of 3185 square miles forms the river, its resources (including the $\mathrm{Ze}$ liba which is 8250 square $\mathrm{km}$ ) (Britannica, 2015), and the four countries share 10 transboundary river basins (IUCN, 2016). The region covered by the river basin is approximately $751,450 \mathrm{~km}^{2}$, distributed as follows: $71,740 \mathrm{~km}^{2}$ for Sierra Leone, $111,370 \mathrm{~km}^{2}$ for Liberia, $245,857 \mathrm{~km}^{2}$ for Guinea, and $322,462 \mathrm{~km}^{2}$ for Côte d'Ivoire (Britannica, 2015). The total population in 2010 was $41,800,000$ (6.29 million for Sierra Leone, 3.33 million for Liberia, 10.21 million for Guinea, and 22 million for Côte d'Ivoire) (IUCN, 2016); and over 40 percent of the inhabitants rely directly on river support for their food and water, and estimates indicate that (Iza, 2018).

\subsection{Methodology}

To assess possible synthesis for achieving SDG 6.5 within the MRU state, this 


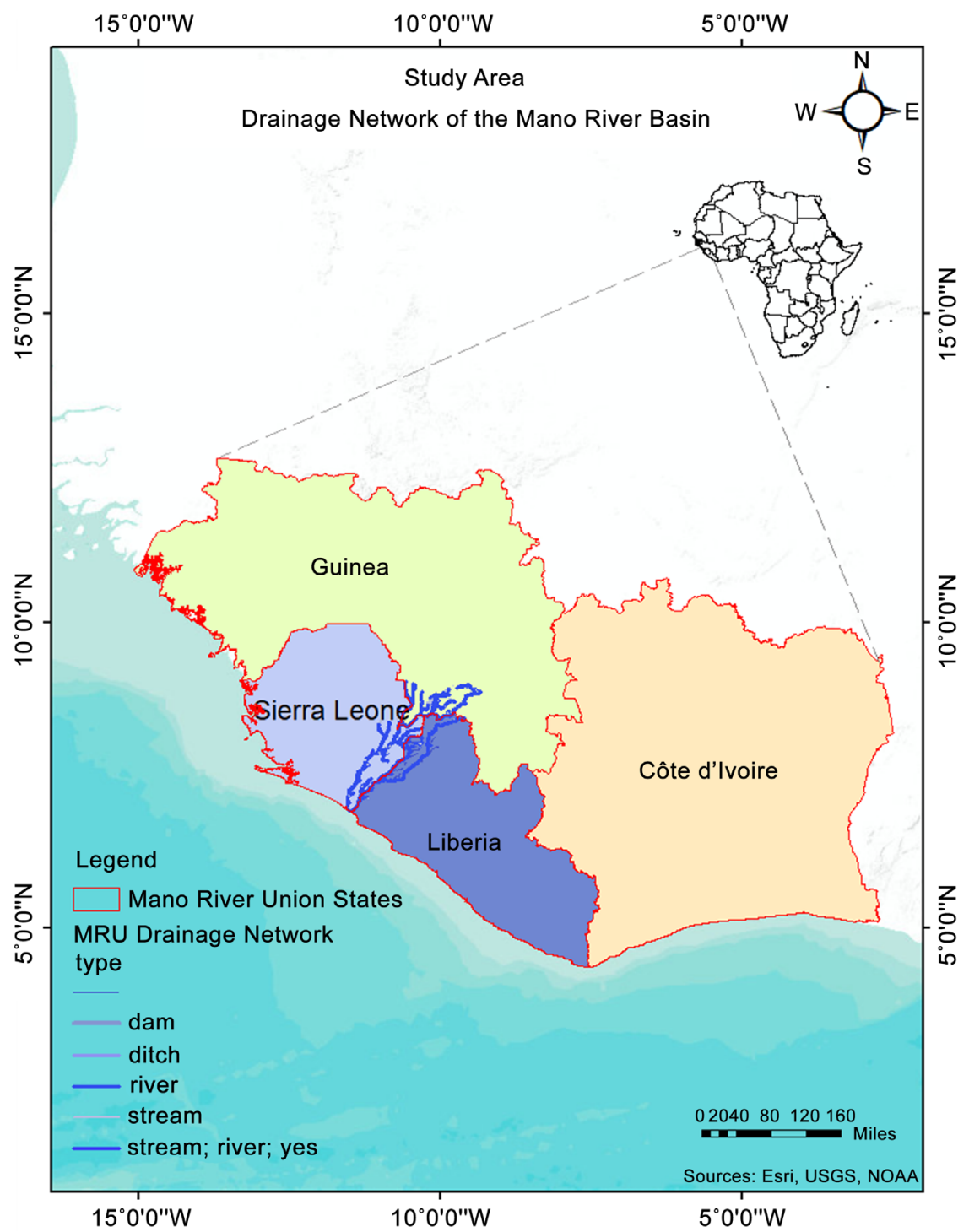

Figure 1. Map of Mano river Union States.

research used the integrative literature approach to examine water management strategies. Published literature on the subject matter within the period of 1974-2020 was accessed using the advanced tools in Web of Science, Scopus or Google Scholar, and grey literature sites (like IUCN, UNEP, etc.). The search terms were developed using keywords; Mano River basin, Mano River union region, water use, transboundary water resources management, and transboundary basin in combination with Boolean operators AND \& OR; (example, River Basin $^{\star}$ AND Water Stress ${ }^{\star}$, River Basin* AND Water Management*, Water Policy ${ }^{\star}$ OR Management ${ }^{\star}$ NOT Strategy ${ }^{\star}$, River basin ${ }^{\star}$ AND Management ${ }^{\star}$ ). Overall, 211 articles were obtained which were further screened based on title, abstract, and keyword evidence. The Integrative Literature review summarizes past studies, draws general conclusions on the issue in question, and offers potential research recommendations (Evans, 2000, Mumbi \& Li, 2020). In this review, the 
basis for choosing to conduct an Integrative Literature approach is as a result of not so much research had been carried out in the Mano River basin. The study, therefore, focuses on water resources collaboration, and regional management of the river basins. The study suggests mechanisms for achieving sustainable IWRM aimed at fostering cooperation and creating water resources for the benefit of all member states. This is because a comprehensive and accurate image of the experienced and current state of river management is essential (Swain, 2011; Nile Basin Initiative, 2012; Mumbi \& Li, 2020).

\subsection{Research Dependability}

The review approach demands efforts to ensure that research findings are reliable and balanced in describing the studies conducted (Hawker, 2002; Mumbi \& $\mathrm{Li}, 2020)$. In the present analysis, steps are taken to ensure trustworthiness (Mumbi \& Li, 2020) as key statistics and records are largely based on the analysis of documentation, including published articles, books, and policy papers. The sources considered were defining, collating, and explaining knowledge on the river water resource basin management that could be used to strengthen and achieve peaceful synchronicity among its Member States in the union. The results of this study look at sustainable river management planning and implementation of SDG 6.5. A step from planning to action, the coordination approach for water utilization and conservation could straighten strategies and facilitate economic integration programs. This would enable multi-lateral cooperation and a joint effort between the member states seeking a win-win for the water resources utilization.

\subsection{The Study Conceptual Framework}

The ability to 1) respond to the requirements of the IWRM and 2) specifically define device actions as a component of time and place is influenced by the selection of method (Nikolic \& Milicevic 2012). The research conceptual framework focuses on experienced situations, management, and future action of the river resources in general. This is because the primary objective of implementing WRM is to meet human and ecological needs and protect against water stress through the simulation of organization structure, coordinated actions, and preferences that embraced and support the concept of sustainable IWRM. The research conceptual framework gives provision for an IWRM relationship which establish systems that capture IWRM in achieving target 6.5 activities based on the current prevailing situation of the river basins. The components of the conceptual framework for this study transmit the requisite information to other participants directly as shown in Figure 2. According to the IWRM concept and to promote the theory of system view, this model will provide an authentic representation of the interactions between the physical environment and implementation of IWRM strategies (Nikolic \& Milicevic 2012; Nikolic \& Simonovic, 2015). The modeling paradigm encourages model scenarios to analyze different issues of "what-if" management (Nikolic \& Simonovic, 2015). 


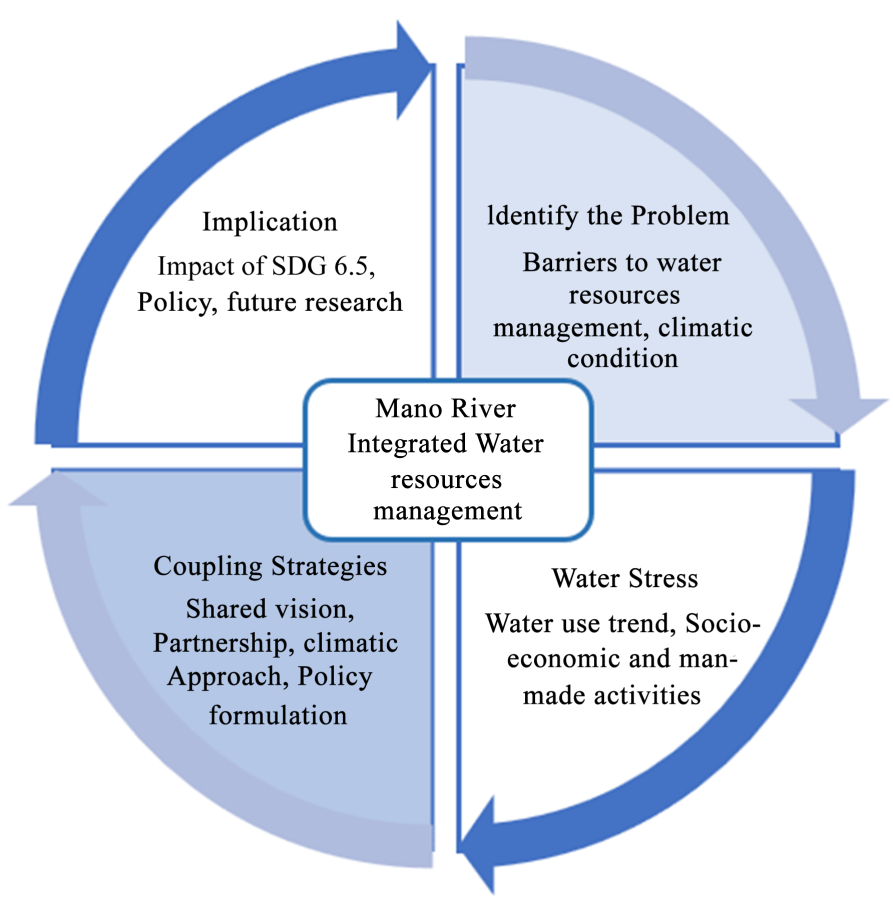

Figure 2. Conceptual framework.

As shown in Figure 2, in terms of the study conceptual framework relationship, the challenges to IWRM were established, and the water stress was assessed to ascertain the region's changing water use trends. The coupling approaches looked at variables that explain IWRM because the related factors can affect the variations in water usage patterns, which are important to pay attention to. The justification for considering the implication derives from the potential for IWRM to be skewed by their results. Finally, the information gathered about the challenges, implications, and coupling strategies would be critical for developing integrated policies and approaches for improved IWRM in the Mano River Ba$\sin$.

\section{Results}

\subsection{Water Use Trend and Its Implication}

The regional scope of the Mano River Union is different from the transboundary Basin of Mano River which is one of the multiple transboundary basins in this area, just like those of Moa/Makona, cavally, Cestos (Sankara-Bassonon et al., 2018). Beyond agriculture, several reports had indicated that the water accessibility in the Mano River basin is gradually declining by factors such as variability in rainfall and pressure from the rapidly rising population (Poole \& Mohammed, 2013; IGC, 2018, Iza, 2018). Rain-fed agriculture is the most common mode of land use in most transboundary rivers, and people in the Mano River Basin are no exception. Climate change and rapid population growth can jeopardize this activity, which could have serious consequences for river water resources and food security. 
Though the recent hydropower project is viewed as a development stride in the region, the MRU countries are all vulnerable amid a long-running socio-political crisis. Due to political instability, Sierra Leone and Liberia, indigent programs have made power networks obsolete. Although Guinea and Côte d'Ivoire seem to be relatively stable, in countries where electricity generation is as low as $2 \%$ in Liberia and Sierra Leone, and $10 \%$ in Guinea, the cost of electricity generation per kWh remains very high, and it is thought to be among the world's lowest electricity generators (Akitani, 2013). These are important to the successful implementation of TWRM (Varis \& Vakkilainen, 2001). However, hydropower, basin settlement patterns, and economic development activities like fishing in the basin areas have increased the basin water stress and changed its pattern (IUCN, 2012; IUCN, 2015; Sankara-Bassonon et al., 2018). The prevailing view is that the present environmental policy of the MRU does not prevent the present occurrences of water stresses in the river basin (IUCN, 2015).

\subsection{Socio-Economic Activities Implication}

TWRM deals with water governance and incorporates many other roles, including management, poverty alleviation, food, etc. (Sokile et al., 2003; Cosgrove \& Loucks, 2015). These are important to the successful implementation of TWRM. The management of water resources has been hampered by a lack of adequate management proceedings both by professionals and locals. Given the slow pace of implementation in the basin, control of the Mano River's transboundary water resources management has been virtually non-existent (UN, 2018; Ladel et al., 2020). To ensure that the governance of the water resources sector is sensitive to the needs and aspirations of different stakeholders, a diverse set of human skills and capabilities is needed, this is evident in the recent report published by United Nations on SDG 6.5 progress (UN, 2018; Ladel et al., 2020) as shown in Table 1. In general, the basin area has a minimum human potential. From an economic view, socioeconomic industries in the region have not transformed

Table 1. SDG 6.5 progress comparison with the MRU member states in the African continent (Ladel et al., 2020).

\begin{tabular}{cc}
\hline $\begin{array}{c}\text { Indicator } \\
6.5 \text { Progress }\end{array}$ & Africa \\
\hline $\begin{array}{c}\text { No Data shared } \\
\text { Very High } \\
\text { High }\end{array}$ & Nauritania \\
Medium-High & $\begin{array}{l}\text { The Gambia, Tanzania, Uganda, Zimbabwe, Benin, Burkina, Cabo } \\
\text { Verde, Mali, Morocco, Mozambique, Namibia, South Africa }\end{array}$ \\
Medium-Low & $\begin{array}{l}\text { Rest of Africa including Zambia (except Low and Very low ones) } \\
\text { Lake Chad basin and Congo basin. }\end{array}$ \\
Low & Guinea, Liberia, Gabon, Sao Tome and Sierra Leone. \\
Very low & Somalia
\end{tabular}


the region basin, as poverty is still prevalent in the region based on the recent trend of economic growth (IUCN, 2012; IUCN, 2015); even though, according to a survey undertaken in 2018, Sierra Leone exported over 2000 metric tons of agricultural products worth over $\$ 1$ million to Guinea and Liberia's neighboring countries through the seven official borders (IGC, 2018). Agriculture, mining, and logging are the mainstay of the MRU countries' economy, and the private sector's growth has remained at a nascent stage (GIZ, 2011).

\subsection{River Management Progress towards SDG 6.5}

SDG 6.5 allows transboundary States to implement IWRM and TWRM corporations over their shared water resources. As per statistics from the 2018 UN report, 19 countries in the Sub-Saharan region with transboundary water resources show that at least $50 \%$ (12) of their transboundary basins have working systems in place, and 5 out of 18 meet the transboundary aquifers threshold (UN, 1992; Ladel et al., 2020). The statistics of the evaluated target have increased since 1995 (Xu et al., 2020b), but three of the MRU countries namely; Guinea, Liberia, and Sierra were ranked low in terms of the progress made on SDG 6.5 (Ladel et al., 2020). One factor that has been viewed as an inconsistent limiting factor of developing countries to achieve this is as a result of lack of legal socio-economic activities amongst them compared to that of developed countries (UN, 2018; Xu et al., 2020b). Noting the implications of this factor in the region's river resources water demand and use patterns, attaining SDG 6.5 will be an all-inclusive step that the MRU countries will take to fully achieve a functional MRU institution on water resources management in the region.

\subsection{Observed Climate Change in the Basin}

The region's resources, which serve as the transboundary link between member states are continuously being overexploited for activities such as agriculture, mining, and timber logging (Akitani, 2013; IUCN, 2016; NVE, 2016); climate change poses serious challenges and threats across numerous rivers due to some of these activities (Di Baldassarre et al., 2011; De Pauw \& Ramasamy, 2020). The observed regional changes due to the climatic conditions can also result in decreased run-off and degrade the river water resources (IUCN, 2016). These changes are particularly vital for the ecosystem resources and inhabitants around the basins area, where the population is exposed to frequent seasonal variability (IUCN, 2016). The 2017 USAID report in the Guinea region shows that biodiversity is threatened by habitat loss (e.g., firewood), creation of settlements (construction purposes), and over-exploitation of fishery resources (USAID, 2017). The climate variation has impacted the region and exacerbates threats such as droughts and coastal erosion, and floods due to fishing resources (USAID, 2017). Several reports show that the forests of Zama-Wonegizi-Wologizi (ZWW) Guinea and Liberia, which maintain the vast intact blocks of the upper Guinea Rainforest along the river basin have decreased significantly from ongo- 
ing forest clearance; and as a result, Guinea's forest areas have dropped by about 33\% to just 444,000 hectares between 1976 and 2013, and between 1998 Liberia's rainforest has decreased by $12.19 \%$ (600,000 ha) (USAID, 2017). The predicted climate change in West Africa is indeterminate due to the region precipitation pattern and the differences forecasted by different models (Wada et al., 2011; Nile Basin Initiative, 2012; IUCN, 2016). Climate change is estimated to aggravate further the uncertainty in annual precipitation and reduced river flow, land degradation, biodegradation, deforestation, and increased disease frequency (Di Baldassarre et al., 2011; Swain, 2011; Wada et al., 2011; Blum, 2019).

\section{Discussion}

\subsection{Factors Influencing the Emergence of Water Stress in the Basins}

Water services have been recognized globally as a tool for community development, peacebuilding, and diplomatic security (Rahaman \& Varis, 2005). The Mano River basin environment has been susceptible to many water stresses and this will replenish the river's vast potential as demands for mining, irrigation, agriculture, and residential use grow (IUCN, 2016). According to the International Union for Conservation of Nature (IUCN), although collaboration in the water sector is at the core center of the union's concerns, the MRU institution does not so far have any specific mandate defining its task in the area of managing the transboundary water resources (Sankara-Bassonon et al., 2018). Until today activities like unstable agriculture and mining, are advancing steadily into the remaining forest areas (IUCN, 2015; IUCN, 2016; NVE, 2016; Teñido 2017); and no legal status protects this broader landscape of the remaining forested areas, even though this situation threatens the survival of many seasonally migrating forest-dwelling animals and river flow (IUCN, 2016). Furthermore, the increasing number of projects consisting of the construction of dams, irrigation canals, or inter-basin transfer systems, which require an overall water management plan also impact water resources in the river basin areas (Akitani, 2013; IUCN, 2016; USAID, 2017). Table 2 gives an insight on the threats, causes, and barriers analysis that has significantly affected the river water and forest ecosystem services, and these factors had led to water stress in the basin community.

\subsection{Implementing a Shared Vision}

There is a high need for transboundary problems to be resolved, which has created various difficulties and disputes worldwide because the quantity of water required demand is more than the water availability (Hojjat Mianabadi, 2013). The objective of the shared vision is to build a strong partnership and network among MRU states to enhance active cooperation at all levels that address SDG 6.5 with other SDGs holistically. Implementing a shared vision strategic objective roadmap on monitoring, evaluation, communications, and resource mobilization strategies will breathe air and life (Neir \& Campana, 2007) into the ongoing 
Table 2. Summary of the threats, root causes, and barriers in the river basins.

\begin{tabular}{|c|c|c|c|c|}
\hline & Threats & Consequences & Root causes & Barrier Analysis \\
\hline $\begin{array}{c}\text { Forest } \\
\text { Ecosystem }\end{array}$ & $\begin{array}{l}\text { Climate-induced: } \\
\text { Bushfires, droughts. } \\
\text { Human-induced: } \\
\text { Agriculture expansion, } \\
\text { Agro-industrial plantations, } \\
\text { Industrial \& artisanal } \\
\text { logging, Mining, Poaching, } \\
\text { Urbanization, Firewood } \\
\text { and charcoal production; } \\
\text { Human intrusions. }\end{array}$ & $\begin{array}{l}\text { Forest fragmentation and } \\
\text { degradation (by farming, new } \\
\text { settlement, roads, and skid } \\
\text { trails), Biodiversity loss, } \\
\text { Large scale ecosystem changes. }\end{array}$ & $\begin{array}{l}\text { Poverty \& population growth, } \\
\text { Lack of governance, } \\
\text { Communities dependence on } \\
\text { natural resources \& Absence } \\
\text { of alternative livelihood } \\
\text { opportunities, and low } \\
\text { economy. }\end{array}$ & $\begin{array}{l}\text { Insufficient understanding } \\
\text { of adequate agroforestry } \\
\text { technologies, Insufficient } \\
\text { demonstration projects, } \\
\text { Insufficient economic } \\
\text { incentives, Inadequate } \\
\text { legal/regulatory basis. }\end{array}$ \\
\hline $\begin{array}{c}\text { Water } \\
\text { Resources }\end{array}$ & $\begin{array}{l}\text { Climate-induced: } \\
\text { A decline in rainfall and } \\
\text { average flows; Water scarcity } \\
\text { during low flows, Floods. } \\
\text { Human-induced: } \\
\text { Urbanization, Soil erosion, } \\
\text { domestic and industrial } \\
\text { pollutions, Mining, } \\
\text { Agriculture expansion, } \\
\text { Agro-industrial plantations. }\end{array}$ & $\begin{array}{l}\text { Water quality degradation } \\
\text { (mining, agro-industrial } \\
\text { plantations discharges } \\
\text { chemicals), Water-borne } \\
\text { diseases, Degradation of } \\
\text { water ecosystems, Growth of } \\
\text { aquatic weeds. }\end{array}$ & $\begin{array}{l}\text { Poverty \& population growth, } \\
\text { Transboundary resources, } \\
\text { Difficulties to access } \\
\text { groundwater reserves of which } \\
\text { very little is exploited today, } \\
\text { Degradation of products and } \\
\text { service functions, and loss of } \\
\text { tree-based vegetation cover. }\end{array}$ & $\begin{array}{l}\text { Lack of hydrological } \\
\text { systematic monitoring and } \\
\text { water-quality data, weak } \\
\text { coordination, national laws, } \\
\text { policies not implemented, } \\
\text { Low capacity of local } \\
\text { institutions and } \\
\text { administration. }\end{array}$ \\
\hline
\end{tabular}

Source: IUCN-Mano River ecosystem conservation and IWRM project.

MRU five-year plan of the river basins. It is very important to point out that meaningful cooperative sharing of the Mano River water resources will contribute to sustainable socio-economic development.

The Global Discussion on Sustainable Development (GCSD), which took place in 2002 in South Africa, is regarded as a success because it put WRM at the topmost of the agenda. The implementation strategy of Global Sustainable Development (GSD) envisages a shared vision as part of TWRM. It sets out concrete goals and guidelines for the global implementation of the TWRM, including the 2005 design of the TWRM and water efficiency plan for all the major river basins. The creation and implementation of national or regional TWRM policies and programs, water efficiency improvement, public-private use facilitation, and partnerships development (Varis \& Vakkilainen, 2001) in the region should be at the core of the implementation strategy. Presently, the MRU and policymakers are working together to include the aspect of an integrated approach to ecosystem management, including the conservation of biodiversity, good governance, and livelihood opportunities for the resident in the basin region communities (USAID, 2017); however, much has not been done on the TWRM.

Long conflicts and crises have weakened the economic and social infrastructure of these West African states, and governments are unable to provide these infrastructures or open up income-generating opportunities during and after the post-conflict period (GIZ, 2011). As a result, a substantial part of the population of the river basin faces economic and social challenges. Working collaboratively 
with the private-sector businesses in the region may play an important role in such a setting, allowing people to work for a living and sustainably earn money with no much effect on the river resources. However, these businesses' success can also be hindered by a shortage of sustainable services, poor public resources, a lack of rule of law, ineffective public authorities, and commercial procedures. However, the TWRM platform should collaborate with strong businesses, whether local or regional, that have the financial and operational resources to cope with the ongoing situations in the basin environment. For example, in India, polycentric water resource governance was implemented at all levels of macro-catchments, from national to regional, provincial, and community levels (Ladel et al., 2020). This is because transboundary water management improves regional integration by fostering better cooperation among states involved.

\subsection{Support and Strengthening Regional Partnership}

The lack of a unified water managerial executive body has become a severe pose facing modern contemporary water objections of the $21^{\text {st }}$ Century (Varis \& Vakkilainen, 2001; Adar, 2011; Mumbi \& Li, 2020). The problem of coordinating, regulating, and using the waters of the Mano river is highly multifaceted. Reducing the magnitude of challenges in the region requires resolving an array of political, legal, administrational, and socio-economic challenges of the river basin system (Demin, 2005). To help culminate locals' and other stakeholders' concerns over water stress, greater responsibility should be laid on all actors to properly manage the water resources arrangement and create conditions for water resources agreement (Sokile et al., 2003). Recognizing all member states' common concerns and interests, the MRU should embark on a participatory dialogue among the state members to fashion a shared vision (Adar, 2011). Water resources treaties should be versatile enough to allow for required changes over time, as water management policies dependent on their fair usage and strategies (Ravnborg, 2004; Silberfein \& Conteh, 2006; Adar, 2011). Transboundary water resource governance can only become depoliticize when all parties involved can access, collect, and store basin-wide data information (Turton, 2003; Adar, 2011). The MRU should also work at the governmental and non-governmental institutions interface, typically the formal bodies that mediate interactions (Armitage et al., 2015).

Strengthening the relationship between member states could also help to achieve activities or combat climate change and reduce deforestation and biodiversity loss. Over the years, the MRU executive body has worked with other secretariats to maintain a cordial working relationship supporting the sustainable management of the river water resources management. Recently, the MRU Member States endorsed a five-year institution strategic plan that will facilitate the attainment of safeguarding the basin through a partnership with other developmental partners. The approved regional five years strategic plan is in line 
with strengthening regional partnership objectives as this will help to promote peace, food security, and socio-economic development (Poole \& Mohammed, 2013). The documents also reflect the commitment to ensure stability and accelerate its four-member countries' economic growth as it considers all national interests. The following could be achieved with such initiative;

1) Benefits deriving from bilateral cooperation and diplomacy.

2) Benefits are more visible in border areas, making it a priority in each country's national development plans.

3) It will help respective governments and development partners like the private sectors in industry expansion, particularly in agriculture, electricity, mining, and tourism.

\subsection{Approaches to Combat Climate Variation}

The rational and sustainable approach for the management of the Mano River climate change should be given serious consideration because the present environments of the basins at all levels do not sufficiently support monitoring of the river climate data. There are limited climate management instruments to monitor the river basin's climatic condition to sustain the water environment. In the 20th Century, dramatic climatic changes were observed in the west Africa monsoon zone, which member states stream along (Varis \& Vakkilainen, 2001; Hartmann et al., 2013). For example, the sub-Saharan monsoon is caused by seasonal shifts due to the intertropical merging zone. The widely held of the world's climate-related catastrophes are associated with monsoons (Varis \& Vakkilainen, 2001). Projected climate changes show a regional downscaled projection of overall mean and maximum temperature change in West Africa, a change which stems from coastal to interior regions (Wada et al., 2011; Nile Basin Initiative, 2012; Hartmann et al., 2013). This is evident as shown in the regional average loss of open water in Figure 3 (UN, 2018).

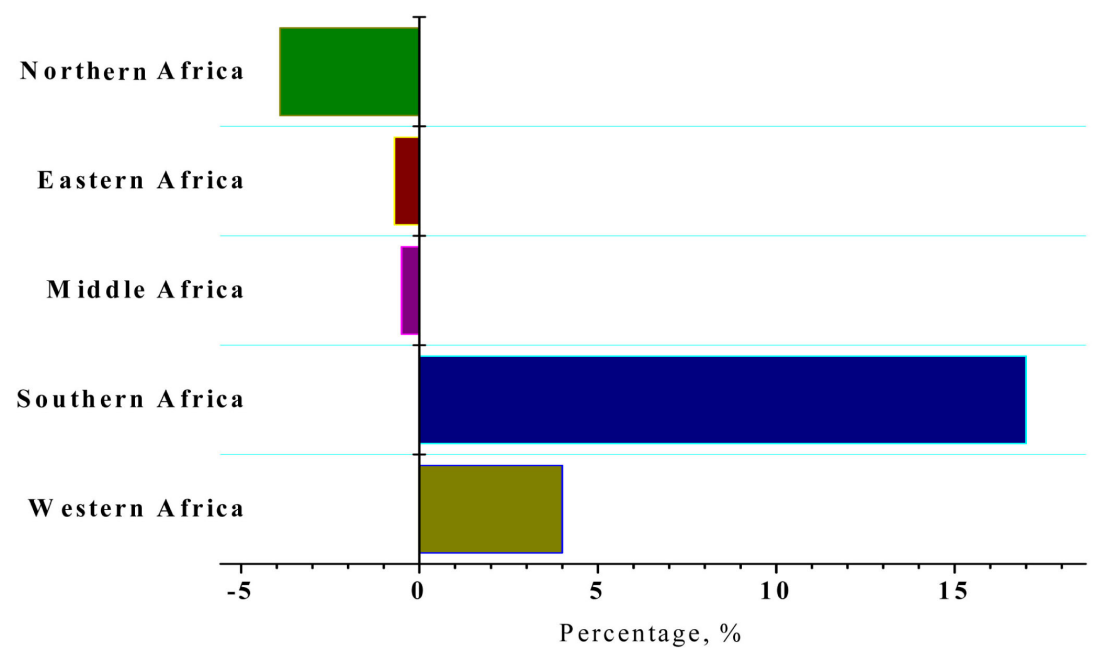

Figure 3. Regional open water trend analysis: average loss and gain from 2001 to 2015 (UN, 2018). 
The climates of MRU states are tropical climate wet, and dry (De Pauw \& Ramasamy, 2020). Sierra Leone's climate is hot with average annual precipitation of $2925 \mathrm{~mm}$ (Masafu et al., 2016; Baggie et al., 2018; Wadsworth et al., 2019); Guinea climate is savanna, the rainforest zone receiving the highest rainfall with an average yearly precipitation of $1280 \mathrm{~mm}$ (Ayanlade et al., 2018); Côte d'Ivoire and Liberia climate are tropical with an average annual precipitation of $1675 \mathrm{~mm}$ and $2500 \mathrm{~mm}$ respectively (Giresse, 2008; Gunn et al., 2018). Analyses of the basin trends in precipitation projections show that average mean twelve-monthly temperatures are anticipated to rise by $1.9^{\circ} \mathrm{C}$ by 2055 (i.e. from $25.6^{\circ} \mathrm{C}$ to $27.5^{\circ} \mathrm{C}$ ), $35 \%$ of the upper Guinean forest area is predicted to have a mean annual temperature increase of $2^{\circ} \mathrm{C}$; the intra-annual change in monthly mean temperatures to remain relatively constant $\left(1.5^{\circ} \mathrm{C}\right)(\mathrm{IUCN}, 2016)$ and the mean maximum monthly temperatures to rise on average by $2055\left(30.5^{\circ} \mathrm{C}\right.$ to $32.3^{\circ} \mathrm{C}$ ) (IUCN, 2015; IUCN, 2016).

Previous research in the River Nile and other transboundary rivers shows that a mean annual rainfall model can be used to obtain climatic data in specific regions based on instrument elevation, latitude, and longitude (Sokile et al., 2003; NVE, 2016). For instance, this method was implemented to determine the significant effects of the elevation and expansion approach to construct the gorges dam in Ethiopia (Conway, 1997; Sokile et al., 2003). At present, the Mano River basins do not have a special model to determine water losses or gain every year that represents roughly $70 \%$ of the whole basin's annual income. Therefore, specialized technical models are required to monitor the in-out flow of water losses or gains in the Mano River basin as this will help to predict how to approach climatic variation in the basin region. Research has shown that implementing SDG 6.5 will bring other benefits as compared to other African programs (see Table 1).

\subsection{Integrated Concept Policy}

Since 1992 to date, all countries with transboundary water resources have started implementing some aspects of IWRM, and it is reported that approximately $75 \%$ of transboundary countries have approved water resources policies and regulations based on integrated methods (UN, 2018). This is evident in the Mano River adaptation of the 2020-2025 strategic plan. However, the national and transnational perspective and decision-making considerations of river water resources management are not centrally based properly (Mekonnen \& Hoekstra, 2014). These plans should look at how to implements the formulated policies and legislation in the river basins. It can be observed that the basin region is facing rapid population expansion, which has resulted in abrupt water stress and many challenges. These stress patterns have impacts on the livelihoods and biodiversity of settlement communities in the basin (Abebe, 2014). For example, the 114,800 ha ZWW forest (endemic to Liberia, Guinea, Côte d'Ivoire, and Sierra Leone forests) faces many complex threats destruction and loss of habitat from agricultural invasion and expansion, abusive timber felling, and wood energy that con- 
tributes to habitat degradation (USAID, 2017).

Integrated policies are simultaneous decision-making needed to address the aspects of environmental impacts that have the potential to be affected by IWRM. The lack of integrated concepts and decision-making can exacerbate these challenges in a manner in which the union can have challenges to implement funded or source-funded projects. It can be recalled that new viewpoints on MRU activities are focused primarily on sustainable socio-economic growth and multidimensional collaboration for their existing framework policies and legislation. This would allow the secretariat to work assiduously, understand lesson-learned concepts from other transboundary rivers, and sharing effective water management strategies; as this enhances local interventions and informs local, national, and regional policies in support of community-based conservation efforts (Boer et al., 2015). The integrated concept policy and decision making should primarily focus on;

1) MRU Policies and legislation that focused on the institutionalization of SDG 6.5 principles through the supportive services and other development sectors of the union to achieve at least more than $75 \%$ by 2030 .

2) Development policies that examine long-term needs for the development of water resources allocation.

3) Integrated decisions that support and promote basin development into local, national, and international water-related policies and strategies.

4) Policies that improve the capacity-building of project staff to facilitate the modelling and evaluation of MRU instruments through planning and integration processes across all sectors.

\subsection{Impact of Achieving Target 6.5}

Implementing strategies is based on prevailing circumstances (political, social, environmental, and economic settings) (UN, 2018). The sustainability of any transboundary river depends on the proper management of its resources; therefore, water management is a dynamic approach that requires comprehensive management for its sustainability (Nikolic \& Simonovic, 2015; Blum, 2019). IWRM is a systemic approach towards resolving the inseparable character of social, environmental, and economic mechanisms associated with water resource management (Nikolic \& Simonovic, 2015) in the Mano River Basin. Globally, about $45 \%-48 \%$ is recorded as the average degree of IWRM implementation (medium-low) but with variations among countries (UN, 2018; Xu et al., 2020a). Looking at progress made on IWRM in the region (see Table 1), it is obvious that modest progress is being made in the MRU region; and by the snail pace of implementation, it is apparent that they will not fully meet the target by 2030 if proper management of the river is not put in place.

\section{Conclusion}

SDG 6.5 envisages a better environment and a better life for the present and fu- 
ture generations of inhabitants living in the transboundary basin. This SDG promotes WRM and river conservation partnerships to ensure accessibility and effective use of water resources to meet current needs without neglecting future generations. For SDG 6.5 to be successful and meet the desired target, shared awareness and the application of values of social and environmental justice must be emphasized in all activities. Furthermore, there should be knowledge transfer of the lessons learned on the progress of SDG 6.5 from other countries/regions, provision of more relevant information and data (to collect, store and monitor the river water and climatic conditions) and the mobilization of funds for Joint MRU states investment in the implementation of the strategic plan and formulation of integrated policies.

\subsection{Implication}

The findings to achieve SDG 6.5, alongside their driving factors in the Mano River basins have important socio-economic as well as sociopolitical, and policy implications for millions of people in the basin, especially in terms of food security and socio-economic development. The recent hydropower construction for the MRU states would not only address the region's shortage of energy, but it will also have a serious change in water pattern usage, given the implications of hydropower's expected water flows and uses; as a result, regional integrated water resources management policymaking will be needed. Water resource management, water quality, water usage, and climate change mitigation are all domains where such policymaking is important. In this case, policy questions regarding new IWRM policies by collaboration are pertinent. Simultaneously, the quality of information and forecasting in recommending policy and decision-making, especially in light of volatility and the need for stable and coherent policies for such a critical river is key. For instance, community-based actions potentially strengthen policymaking, but most policymaking focuses on higher-level factors, leaving out more geographic concerns. However, river basin management through community-based approaches developed by other transboundary rivers in their socio-economic region will offer alternatives to MRU countries along the basin.

\subsection{Regional Outlook}

Water Resources Management is considered as a global outlook; however, it is also imperative to consider its existing state regionally, given the expected decrease in water resources and its availability. This, in particular, aids in the planning of future decisions and, when possible, the resolution of issues. While this review focuses primarily on SDG 6.5, it is difficult to avoid connecting the issue to other SDGs, and therefore such an approach will prompt a suitable consideration of IWRM and WRM. Several reports have shown that a strong regional outlook and framework are critical in fostering transboundary water cooperation among the MRU member states. Furthermore, given the current economic situation and progress on SDG 6.5, the MRU states should also seek supportive lea- 
dership, and funding to design a roadmap for the adoption of the IWRM framework, work in collaboration with the UN Environment Program's Water and Environment Centre (UNEP-DHI) for supportive technical assistance, as well as the Economic Community of West African State (ECOWAS) Water Resources Coordination Centre. Such an approach could help member states revise their collaboration implementation strategy and policies to deliver benefits that could lead to a much better synthesis to achieve SDG 6.5.

\subsection{Future Perspectives}

One of the most important areas for potential study to achieve SDG 6.5 in the Mano basin is designing climatic models, and designing case scenarios for socio-economic activities and water usage trends. The present and potential effects of hydropower for the Mano Basin are another critical field to which the MRU secretariat should pay attention. Finally, an integrated policy process that focuses on proper water use and sharing for a better understanding of the present and potential state of the Mano River's water resources; as such policies can draw on both transboundary and basins community perspectives.

\section{Acknowledgements}

The authors expressed their gratitude to all who helped make this work a success.

\section{Declaration of Funding}

Tongji University provided funding for this research through a study scholarship.

\section{Conflicts of Interest}

The authors declare that they have no conflict of interest.

\section{References}

Abebe, D. (2014). Egypt, Ethiopia, and the Nile: The Economics of International Water Law. Public Law and Legal Theory Working Paper No. 484, Chicago, IL: University of Chicago.

Adar, K. G. (2011). Kenya's Foreign-Policy and Geopolitical Interests: The Case of the Nile River Basin. African Sociological Review, 11, 63-80. https://doi.org/10.4314/asr.v11i1.51440

Akitani, E. (2013). Pioneering Energy Project to Bring Relief to Mano River Union Countries.

https://www.afdb.org/en/news-and-events/pioneering-energy-project-to-bring-relief-to -mano-river-union-countries-12527

Armitage, D., de Loë, R. C., Morris, M., Edwards, T. W. D., Andrea, R. I. H., Gerlak, K., Huitema, D., Ison, R., Livingstone, D., MacDonald, G., Mirumachi, N., Plummer, R., \& Wolfe, B. B. (2015). Science-Policy Processes for Transboundary Water Governance. Ambio, 44, 353-366. https://doi.org/10.1007/s13280-015-0644-x

Ashour, M. A., Aly, T. E., \& Abueleyon, M. (2019). Transboundary Water Resources “A 
Comparative Study": The Lessons Learnt to Help Solve the Nile Basin Water Conflict. Limnological Review, 19, 3-14. https://doi.org/10.2478/limre-2019-0001

Ayanlade, A., Radeny, M., Morton, J. F., \& Muchaba, T. (2018). Rainfall Variability and Drought Characteristics in Two Agro-Climatic Zones: An Assessment of Climate Change Challenges in Africa. Science of the Total Environment, 630, 728-737.

Baggie, I., Sumah, F., Zwart, S. J., Sawyerr, P., Bandabla, T., \& Kamara, C. S. (2018). Characterization of the Mangrove Swamp Rice Soils along the Great Scarcies River in Sierra Leone Using Principal Component Analysis. Catena, 163, 54-62.

Blum, A.G., Alexander, Z. B., Alexander, S., Wu, S., Zhang, Y., Shukla, S., Alemneh T., \& Block, P. (2019). A Grand Prediction: Communicating and Evaluating 2018 Summertime Upper Blue Nile Rainfall and Streamflow Forecasts in Preparation for Ethiopia's New Dam. Frontiers in Water, 1, Article No. 3. https://doi.org/10.3389/frwa.2019.00003

Boer, B., Hirsch, P., Johns, F., Saul, B., \& Scurrah, N (2015). The Mekong: A Socio-Legal Approach to River Basin Development (1st ed.). London: Routledge. https://doi.org/10.4324/9781315765556

Britannica, The Editors of Encyclopaedia (2015). Mano River. Encyclopedia Britannica. https://www.britannica.com/place/Mano-River

Conway, D. (1997). A Water Balance Model of the Upper Blue Nile in Ethiopia. Hydrological Sciences Journal, 42, 265-286. https://doi.org/10.1080/02626669709492024

Cosgrove, W. J., \& Loucks, D. P. (2015). Water Management: Current and Future Challenges and Research Directions. Water Resources Research, 51, 4823-4839. https://doi.org/10.1002/2014WR016869

De Pauw, E., \& Ramasamy, S. (2020). Rapid Detection of Stressed Agricultural Environments in Africa under Climatic Change 2000-2050 Using Agricultural Resource Indices and a Hotspot Mapping Approach. Weather and Climate Extremes, 27, Article ID: 100211. https://doi.org/10.1016/j.wace.2019.100211

Demin, A. P. (2005). Distribution of Water Resources: A Case Study of the Transboundary Nile River. Geography and Natural Resources, 36, 198-205. https://doi.org/10.1134/S1875372815020134

Di Baldassarre, G., Elshamy, M., van Griensven, A., Soliman, E., Kigobe, M., Ndomba, P., \& Solomatine, D (2011). Future Hydrology and Climate in the River Nile Basin: A Review. Hydrological Sciences Journal, 56, 199-211. https://doi.org/10.1080/02626667.2011.557378

Evans, D., \& Kowanko, I. (2000). Literature Reviews: Evolution of a Research Methodology. The Australian Journal of Advanced Nursing, 18, 33-38.

Giresse, P. (2008). Atmospheric Circulation Climatic Mechanisms and African Climate. Developments in Quaternary Science, 10, 7-13. https://doi.org/10.1016/S1571-0866(08)80004-8

GIZ (Deutsche Gesellschaft für Internationale Zusammenarbeit) (2011). PPP Fund for Cooperation with Companies in Mano River Union Countries. Côte d'Ivoire, Liberia, Guinea and Sierra Leone: German Federal Ministry for Economic Cooperation and Development (BMZ), Co-Funded by European Union (EU).

Gunn, A. G., Dorbor, J. K., Mankelow, J. M., Lusty, P. A. J., Deady, E. A., Shaw, R. A., \& Goodenough, K. M. (2018). A Review of the Mineral Potential of Liberia. Ore Geology Reviews, 101, 413-431. https://doi.org/10.1016/j.oregeorev.2018.07.021

Hartmann, D. L., Klein Tank, A. M. G., Rusticucci, M., Alexander, L. V., Brönnimann, S., Charabi, Y., Dentener, F. J., Dlugokencky, E. J., Easterling, D. R., Kaplan, A., Soden, B. 
J., Thorne, P. W., Wild, M., \& Zhai, P. M. (2013). Observations: Atmosphere and Surface. In T. F. Stocker, D. Qin, G. K. Plattner, M. Tignor, S. K. Allen, J. Boschung, A. Nauels, Y. Xia, V. Bex, \& P. M. Midgley (Eds.), Climate Change 2013: The Physical Science Basis: Contribution of Working Group I to the Fifth Assessment Report of the Intergovernmental Panel on Climate Change (pp. 15-24). Cambridge: Cambridge University Press.

Hawker, S., Payne, S., Kerr, C., Hardey, M., \& Powell, J (2002). Appraising the Evidence: Reviewing Disparate Data Systematically. Qualitative Health Research, 12, 1284-1299. https://doi.org/10.1177\%2F1049732302238251

IGC (International Growth Centre) (2018). Sierra Leone Policy Brief 39403: The Realities of Cross-Border Trade between Sierra Leone and Its Neighbours. Freetown: Centre for Economic Research and Capacity Building. https://www.theigc.org/

IUCN (International Union for Conservation of Nature) (2012). Mano River Union Ecosystem Conservation and International Water Resources Management (IWRM) Project. Regional: Mano River Countries, GEF Trust Fund. 62,977,006.00 USD. Gland: International Union for Conservation of Nature.

IUCN (International Union for Conservation of Nature) (2015). International Union for Conservation of Nature and United Nations Environment Programme-World Conservation Monitoring Centre, EcosystemProfile: Guinean Forests of West Africa Biodiversity Hotspot Ecosystem Profile, Final Draft for Submission to the Critical Ecosystem Partnership Fund.

https://www.birdlife.org/africa/projects/cepf-investment-guinean-forests-west-africa-bi odiversity-hotspot

IUCN (International Union for Conservation of Nature) (2016). Mano River Ecosystem Conservation and International Water Resources Management (IWRM) Project (Vol. 3, pp. 1-141). Gland: International Union for Conservation of Nature.

Iza, D. A. (2018). Prompting and Strengthening Transboundary Water Cooperation: Can a Benefit Focus Help? Gland: International Union for Conservation of Nature. https://unece.org/fileadmin/DAM/env/documents/2018/WAT/02Feb 06-07 Benefits WS Geneva/1.2 IUCN Iza PromptingCoop.pdf

Ladel, J., Mehta, M., Gulemvuga, G., \& Namayanga, L. (2020). Water Policy on SDG 6.5 Implementation: Progress in Integrated \& Transboundary Water Resources Management Implementation. World Water Policy, 6, 115-133.

https://doi.org/10.1002/wwp2.12025

Masafu, C. K., Trigg, M. A., Carter, R., \& Howden, N. J. K. (2016). Water Availability and Agricultural Demand: An Assessment Framework Using Global Datasets in a Data Scarce Catchment, Rokel-Seli River, Sierra Leone. Journal of Hydrology: Regional Studies, 8, 222-234.

Mekonnen, M. M., \& Hoekstra, A. Y. (2014). Water Conservation through Trade: The Case of Kenya. Water International, 39, 451-468. https://doi.org/10.1080/02508060.2014.922014

Mianabadi, H., Mostert, E., Zarghami, M., \& Giesen, N. V. D. (2013). Transboundary Water Resources Allocation Using Bankruptcy Theory: Case Study of Euphrates and Tigris Rivers. Proceedings of the TWAM2013 International Conference \& Workshops, Aveiro, 16-20 March 2013, 1-5.

Mumbi, A. W., \& Li, F. T. (2020). Exploring Changes in Water Use Patterns, Demand and Stress along the Nile River Basin through the Lens of Kenya and Egypt. Marine and Freshwater Research, 71, 1478-1487. https://doi.org/10.1071/MF19396

Nile Basin Initiative (2012). Chapter 2. The Water Resources of the Nile Basin. In State of 
the River Nile Basin (pp. 25-256). Entebbe, Uganda: Nile Basin Initiative. http://nileis.nilebasin.org/system/files/Nile\%20SoB\%20Report\%20Chpater\%202\%20-\% 20Water\%20resources.pdf

Neir, A. M., \& Campana, M. E (2007). The Peaceful Resolution of US-Mexican Transboundary Water Disputes. The Economics of Peace and Security Journal, 2, 42-48. https://doi.org/10.15355/epsj.2.2.42

Nikolic, V. V., \& Simonovic, S. P. (2015). Multi-Method Modeling Framework for Support of Integrated Water Resources Management. Environmental Processes, 2, 461-483. https://doi.org/10.1007/s40710-015-0082-6

Nikolic, V. V., Simonovic, S. P., \& Milicevic, B. D. (2012). Analytical Support for Integrated Water Resources Management: A New Method for Addressing Spatial and Temporal Variability. Water Resources Management, 26, 1063-1086.

NVE (Hydro Consulting) (2016). Hydro Consulting: Liberia River Basins: 2016 Drainage Divisions and River Basin Boundaries (pp. 1-17). Liberia: Ministry of Lands Liberian Hydrological Service, Mines and Energy.

Poole, M., \& Mohammed, J. A. (2013). Border Community Security: Mano River Union Region (pp. 1-52). London: Conciliation Resources.

Rahaman, M. M., \& Varis, O. (2005). Integrated Water Resources Management: Evolution, Prospects and Future Challenges. Sustainability: Science, Practice and Policy, 1, 15-21. https://doi.org/10.1080/15487733.2005.11907961

Ravnborg, H. M. E. (2004). Water and Conflict. Conflict Prevention and Mitigation in Water Resources Management. DIIS Report 2004: 2, Copenhagen: Danish Institute of International Studies.

Sankara-Bassonon, S., Awaiss, A., \& Rocca, M. (2018). Building Dialogue to Enhance Governance of Shared Water Resources in the Mano and Moa/Makona Transboundary Basins (pp. 1-12). Gland: International Union for Conservation of Nature and IUCN West and Central Africa Regional Office. https://portals.iucn.org/library/node/47881

Silberfein, M., \& Conteh, A.-H. (2006). Boundaries and Conflict in the Mano River Region of West Africa. Conflict Management and Peace Science, 23, 343-361. https://doi.org/10.1080\%2F07388940600972685

Sokile, C. S., Kashaigili, J. J., \& Kadigi, R. M. J. (2003) Towards an Integrated Water Resource Management in Tanzania: The Role of Appropriate Institutional Framework in Rufiji Basin. Physics and Chemistry of the Earth Parts $A / B / C, 28,1015-1023$.

Swain, A. (2011). Challenges for Water Sharing in the Nile Basin: Changing Geo-Politics and Changing Climate. Hydrological Sciences Journal, 56, 687-702. https://doi.org/10.1080/02626667.2011.577037

Teñido, I. (2017). Transboundary Water Resources Management: A Case Study of Africa (pp. 1-18). Environment@List. https://environmentlists.org/2017/08/07/transboundary-water-resources-managementa-case-study-of-africa/

Turton, A. R. (2003). A Southern African Perspective on Transboundary Water Resource Management. Environmental Change and Security Project Report, No. 9, 75-87.

UN (United Nations) (1974). United Nations Treaty Series: The Mano River Union Declaration (Vol. 952, No. 1-13608). New York, NY: United Nations. https://wits.worldbank.org/GPTAD/PDF/archive/MRU.pdf

UN (United Nations) (1992). Agenda 21. United Nations Conference on Environment and Development (UNCED). June Rio de Janeiro, 13-14 June 1992. https://www.un.org/en/conferences/environment/rio1992 
UN (United Nations) (2018). SDG 6 Synthesis Report 2018 on Water and Sanitation. New York, NY: United Nations. https://doi.org/10.18356/e8fc060b-en

https://www.unwater.org/publication categories/sdg-6-synthesis-report-2018-on-water -and-sanitation/

USAID (United States Agency for International Development) (2017). Abridge Report-West Africa Biodiversity and Climate Change (WA BiCC): Climate Change Vulnerability Assessment in Mangrove Regions of Sierra Leone. Washington DC: United States Agency for International Development.

https://www.wabicc.org/climate-change-vulnerability-assessment-in-mangrove-regions -of-sierra-leone/

Varis, O., \& Vakkilainen, P. (2001). China’s 8 Challenges to Water Resources Management in the First Quarter of the 21st Century. Geomorphology, 41, 93-104. https://doi.org/10.1016/S0169-555X(01)00107-6

Wada, Y., Van Beek, L. P. H., Viviroli, D., Dürr, H. H., Weingartner, R., \& Bierkens, M. F. (2011). Global Monthly Water Stress: 2. Water Demand and Severity of Water Stress. Water Resources Research, 47, Article No. W07518. https://doi.org/10.1029/2010WR009792

Wadsworth, R., Jalloh, A., \& Lebbie, A. (2019). Changes in Rainfall in Sierra Leone: 1981-2018. Climate, 7, Article No. 144. https://doi.org/10.3390/cli7120144

Whittington, D., Wu, X., \& Sadoff, C. (2005). Water Resources Management in the Nile Basin: The Economic Value of Cooperation. Water Policy, 7, 227-252. https://doi.org/10.2166/wp.2005.0015

Xu, Z., Chau, S. N., Chen, X., Zhang, J., Li, Y., Dietz, T., Wang, J., Winkler, J. A., Fan, F., Huang, B., Li, S., Wu, S., Herzberger, A., Tang, Y., Hong, D., Li, Y., \& Liu, J. (2020a). Assessing Progress towards Sustainable Development over Space and Time. Nature, 577, 74-78. https://doi.org/10.1038/s41586-019-1846-3

Xu, Z., Li, Y., Chau, S. N., Dietz, T., Li, C., Wan, L., Zhang, J., Zhang, L., Li, Y., Chung, M. G., \& Liu, J. (2020b). Impacts of International Trade on Global Sustainable Development. Nature Sustainability, 3, 964-971. https://doi.org/10.1038/s41893-020-0572-Z 